Авдеев Д.А., Кувшинов А.М.

\title{
ОБ ОПТИМИЗАЦИИ ДЕЯТЕЛЬНОСТИ ГЛАВЫ СУБЪЕКТА ФЕДЕРАЦИИ (РОССИЙСКИЙ И ГЕРМАНСКИЙ ОПЫТ)
}

\begin{abstract}
Аннотация: В статье анализируется правовой статус высшего должностного лица субъекта федераџии. Рассматривается отечественный и германский опыт конституционно-правового регулирования данного института. Проводится сравнительный анализ различных аспектов деятельности высшего должностного лииа в Российской Федерачии и Федеративной Республике Германия: порядка его формирования, компетениии, основы взаимоотнотений с региональным парламентом, доля его участия в деятельности федеральных органов государственной власти, основания прекращения полномочий главы субъекта Федерачии.В ходе исследования выделяются общие черты и национальные особенности рассматриваемого института в Российской Федерации и Федеративной республики Германии (на примере отдельных субъектов федераиии). На основании чего анализируются признаки моделей организаџии и деятельности главы субъекта Федерации, установленные российском законодательством. Основными методами данного исследования являются системно-структурный метод, технико-юридический метод и сравнительно-правовой метод. Проведенное исследование позволяет прийти к выводу, что в Федеральном законе от 6 октября 1999 года №-184 Ф3 «Об общих принципах организации законодательных (представительных) и исполнительных органов государственной власти субъектов Российской Федерачии» фактически одновременно закрепляются две исключающие друг друга правовые модели организаџии деятельности высшего должностного лица субъекта Федерации, основанные на кониепииях децентрализованного и иентрализованного типа публичного управления. Сучетом исторического опыта отечественного публичного управления авторами обосновывается целесообразность применения в современных условиях организации системы органов государственной власти субъекта Российской Федерации «иентрализованной» модели деятельности главы субъекта Федераиии.
\end{abstract}

Ключевые слова: Высшее должностное лицо, губернатор, глава правительства, министр-президент, глава субъекта, конституционно-правовой статус, органы исполнительной власти, субъект федерации, Германия, федеральная земля.

Abstract: This article analyzes the legal status of the highest official of a subject of Russian Federation. The authors explore the Russian and German experience in the constitutional law regulation of this institution. A comparative analysis is conducted on various aspects of the work of the highest official in the Russian Federation and the Federative Republic of Germany: order of its formation, competence, foundation of its relations with regional parliament, share of its participation in the work of the federal branches of the government, as well as the basis for termination of the authority of a head of the subject of the federation. The research highlights the common features and national peculiarities of this institution within Russian Federation and the Federative Republic of Germany (on the example of specific federal subjects). The conducted allowed the authors to come to a conclusion that the Federal Law from October 6, 1999 No. 184-FZ "On the General Principles of Organization of the Legislative (Representative) and Executive Branches of Government Authority of the Subjects of Russian Federation" simultaneously establishes two mutually excluding legal models of work organizations of the highest official of the subject of federation, based on the concepts of decentralized and centralized type of public administration.

Keywords: Highest official, head of government, Minister-President, head of subject, constitutional legal status, governor, government executive bodies of federative subject, federal constituent, Germany, federal land.

есспорно, что ключевая роль в публичном управлении регионом принадлежит единоличному органу - главе субъекта Федерации. За время существования данного института сложилась определенная практика его организационнофункциональной деятельности, что не раз становилось предметом рассмотрения. В связи с чем в юридической литературе высказывались различного рода предложения, касающиеся дальнейшего развития конституционно-правового статуса высшего должностного лица субъекта Российской Федерации.

Полагаем, что использование зарубежного опыта в какой-то степени может способствовать совершенствованию тех или иных элементов правового статуса, порядка формирования и компетенционных полномочий главы субъекта Федерации. В данном 
случае представляет интерес опыт Федеративной республики Германии, где рассматриваемый нами институт существует более ста лет и соответственно имеется достаточная практика его деятельности.

Прежде всего, рассмотрим некоторые положения, регламентирующие основу правового статуса главы субъекта Федерации в Германии. Согласно ч.1 ст. 70 Основного Германии [7] субъекты федерации - федеральные земли имеют право законодательного регулирования в сфере, не отнесенной Основным законом к федеральным полномочиям. Статьи 73 и 74 устанавливают исчерпывающий перечень вопросов, отнесенных к исключительному ведению Федерации и конкурирующему законодательству федерации и земель соответственно. Организация публичной власти в землях не входит в компетенцию Федерации, а является предметом ведения земель.

Основы статуса высшего должностного лица федеральной земли закрепляются в конституции соответствующей земли, отдельные положения конкретизируются и развиваются в регламентах парламентов (ландтагов) и правительств земель.

Следует отметить, что наименование высшего должностного лица - Министр-президент - аналогично во всех землях, кроме Берлина, Бремена и Гамбурга в силу их особого статуса городов-государств (аналогичного статусу городов федерального значения в Российской Федерации). Так, высшим должностным лицом Берлина является Правящий бургомистр (ст. 55 конституции земли (далее - к.з.)) [24], в Бремене - Бургомистр (ст. 114 к.3.) [12] и в Гамбурге - Первый бургомистр (ст. 42 к.з.) [10]. Поскольку должность бургомистра, как правило, устанавливается на муниципальном уровне, такое наименование высшего должностного лица дополнительно подчеркивает двойной статус городов-государств.

Хотелось бы рассмотреть требования, которые предъявляются к кандидатам на данные должности. Так, во всех землях Германии устанавливается запрет для министров-президентов занимать иные должности и заниматься иной оплачиваемой деятельностью, однако, встречаются исключения. Так, согласно ст. 45 Конституции земли Мекленбург - Передняя Померания [18] парламент может допустить членство Министра-президента в управляющих органах предприятия, право собственности на которое полностью или в доле принадлежит федеральной земле. Согласно статье 34 Конституции Нижней Саксонии [9] аналогичное разрешение может быть выдано правительством.

Говоря о наделении лица полномочиями Министрапрезидента, стоит отметить, что не все конституции земель содержат четкие критерии, предъявляемые к кандидату на данную должность. Только конституция Баварии [11] в ст. 44 определяет, что избранным может быть каждый баварец, обладающий пассивным избирательным правом и достигший возраста 40 лет. Еще три конституции земель (Бремен, Гамбург и БаденВюрттемберг) указывают на возможность избрания любого лица, которое имеет права избираться в земельный парламент. В конституциях Бремена и Гамбурга прямо указывается на отсутствие ценза оседлости для кандидата на должность министра-президента.

Примечательно, что в конституциях других двенадцати земель отсутствуют какие-либо критерии. Следует отметить, что аналогичная ситуация наблюдается и на федеральном уровне: Основной закон Германии не содержит критериев для кандидата на должность федерального канцлера. Однако данный факт не рассматривается немецкими юристами как пробел нормативного регулирования. Так, профессора Х.Д. Йарасс и Б. Пирот [6] считают, что в случае отсутствия прямо установленных критериев следует руководствоваться методом аналогии закона, то есть на должность канцлера, может быть выбрано любое лицо, имеющее право избираться в федеральный парламент согласно ст. 12 и 15 Федерального закона о выборах [1]. Подобная аналогия допустима и на уровне федеральных земель: регламенты деятельности региональных парламентов (ландтагов) устанавливают требования к лицу, претендующему на должность депутата ландтага. Для большинства земель это немецкое гражданство, достижение совершеннолетия и проживание в соответствующей земле в течение 3 месяцев. Эти же требования можно применять к кандидату на должность министрапрезидента, если конституция земли не содержит соответствующих требований.

Что же касается порядка формирования главы субъекта федерации в Германии, то по общему правилу министр-президент избирается парламентом земли. Конституции некоторых земель предусматривают для этого конкретный срок, нарушение которого влечет за собой, как правило, роспуск парламента. В отдельных землях несоблюдение этого срока означает конституционную обязанность парламента провести заседание по вопросу роспуска, однако, депутаты имеют право проголосовать против роспуска. Логика закрепления такой процедуры состоит в предположении, что невозможность выбора Министра-президента обусловлена политическими перипетиями внутри парламента и парламент соответственно не жизнеспособен.

Полномочия Министра-президента в целом идентичны во всех землях и охватывают назначение и лише- 
ние полномочий министров земельного правительства, определение директив (приоритетов) в деятельности правительства, ведение заседаний правительства и организация его деятельности, права помилования и представительство земли во внешних сношениях (в том числе и в отношениях с федерацией). В некоторых землях отдельные функции принадлежат не Министрупрезиденту, а всему правительству. Так, например, ст. 93 Конституции земли Саарланд [21] содержит бланкетную норму, отсылающую к региональному закону о помиловании, в соответствии со ст. 3 которого право помилования реализуется всем правительством. Также в землях Нижняя Саксония (ст. 38 к.з.), Северный РейнВестфалия (ст. 58 к.з.) [22], Саарланд (ст. 92 к.з.), Гамбург (ст. 44 к.з.), Бремен (ст. 120 к.з.), Бавария (ст. 55 к.з.) и Гессен (ст. 108 к.з.) [17] правительство назначает и лишает полномочий судей и региональных государственных служащих, тогда как в остальных землях это полномочия Министра-президента.

Кроме того, в Бремене согласно ст. 120 конституции земли право представительства земли во внешних сношениях принадлежит каждому министру в пределах закрепленной за ним сферы ответственности. Это отличие означает также, что право подписания договоров от лица земли принадлежит не только Министру-президенту. В Гамбурге же согласно ст. 34 Конституции земли [10] Министр-президент имеет право только назначать и лишать полномочий министров - все остальные полномочия, в том числе и представительские, принадлежат правительству, называемому сенатом.

Немецкие юристы В. Дрекселиус и Р. Вебер в своих комментариях к Конституции Гамбурга [30] указывают, что Гамбург формально не имеет высшего должностного лица и поэтому его функции принадлежат коллегиальному сенату. Однако, как при подписании договора, так и при его ратификации соответствующие полномочия могут быть делегированы конкретному лицу. К. Давид отмечает, что в рамках работы комиссии по вопросам городов-государств было предложено унифицировать законодательство Гамбурга и Бремена о представительстве земель во внешних сношениях по примеру Берлина и закрепить соответствующие полномочия за руководителем правительства (даже если он не имеет отдельного конституционного статуса как высшее должностное лицо земли) [8]. Однако это предложение было отклонено.

Говоря о досрочном прекращении полномочий Министра-президента, стоит отметить, что наряду с добровольной отставкой существует еще два основания прекращения полномочий: выражение недоверия со стороны парламента и вопрос о доверии, поставленный перед парламентом и не получивший поддержки более чем половины депутатов. Однако право Министра-президента поставить вопрос о доверии имеется не во всех землях. Также в отдельных землях конституция закрепляет право народа отозвать Министра-президента, однако, представляется нецелесообразным рассматривать данный институт отдельно, поскольку парламент, отзывая Министрапрезидента, выступает также от лица народа. Таким образом, отзыв Министра-президента народом является частью того же института отзыва, реализуемого непосредственно в форме прямой демократии. Как правило, Министр-президент исполняет свои обязанности до момента непосредственного вступления в должность нового Министра-президента, но, к примеру, в Гамбурге согласно статье 44 земельной конституции обязанности Министра-президента временно исполняет Председатель парламента.

Федеральный конституционный суд Германии трактует доверие согласно конституционно-исторической традиции как формально закрепленную текущую поддержку личности и программы бундесканцлера со стороны депутатов Бундестага[2]. Таким образом, понятие доверия не содержит указания на невыполнение или ненадлежащее выполнение обязанностей федеральным канцлером, но определяется исключительно политическими факторами, т.е. согласием федерального Парламента продолжать работу с канцлером или даже терпеть его наличие [3].

Аналогичная ситуация имеет место с институтом вотума недоверия на уровне федеральных земель. Примечательно, что конституции земель устанавливают различное число депутатов, необходимое для внесения на голосование ландтага предложения о вынесении вотума недоверия Министру-президенту. Так, например, в землях Мекленбург - Передняя Померания (ст. 50 к.з.) и Нижняя Саксония (ст. 32 к.з.) это треть от всех депутатов, четверть - в Бремене (ст. 110 к.з.) и Саксонии-Ангальт (ст. 72 к.з.) [19], одна шестая - в Гессене (ст. 114 к.з.). В Саарланде (ст. 88) вотум может быть выдвинуть исключительно фракцией, в Тюрингии (ст. 73 к.3.) [14]- либо 1/5 от общего числа депутатов, либо фракция, в Берлине также четверть или фракция (ст. 45 Регламента Дома депутатов (парламента Берлина)) [25].

В Баварии предложение вынести вотум недоверия министру-президенту выдвигается фракцией или 20 членами парламента согласно ст. 61 Регламента Ландтага Баварии [26].

Согласно ст. 55 Регламента ландтага земли БаденВюртемберг [27] предложение о выражении вотума недоверия требует поддержки четверти от общего числа 
депутатов либо двух фракций, однако подать заявление депутат может единолично. В землях Райнланд-Пфальц (ст. 50 Регламента Ландтага земли) [28] и ШлезвигГольштейн (ст. 34 Регламента Ландтага земли) [29] предложение должно быть подписано 16 депутатами и 18 депутатами либо 2 фракциями соответственно. В Бранденбурге [16], Северный Рейн-Вестфалии и Саксонии [13] данной вопрос нормативно не урегулирован и каждый депутат может выдвинуть предложение о вынесении вотума недоверия министру-президенту, которое в любом случае требует одобрения абсолютного большинства депутатов путем голосования. Кроме того, соответствующая норма содержится в отдельных землях в конституции, в других - в регламенте земельного парламента.

Рассматриваемый нами институт недоверия в Германии получил название как «конструктивный вотум». Его «конструктивность» заключается в обязательном представление кандидатуры нового Министра-президента. Если новый Министрпрезидент не избран в течение установленного срока, то в большинстве земель это означает простую недействительность вотума и дальнейшее исполнение Министром-президентом своих обязанностей. Однако в землях Бавария (ст. 44 к. з.), Райнланд-Пфальц (ст. 99 к. 3.), Тюрингия (ст. 50 к. з.), Саксония-Ангальт (ст. 73 к. 3.) и Гессен (ст. 114 к. з.) неизбрание нового Министрапрезидента предполагает роспуск парламента.

Представляет интерес использование вотума недоверия в Баварии, Конституция которой [10] не закрепляет институт вотума как таковой, однако устанавливает в статье 44 обязанность Министрапрезидента подать в отставку в случае, если политические отношения делают невозможным основанное на доверии взаимодействие его и парламента. Статья 61 регламента ландтага Баварии [5] конкретизирует эту норму, указывая, что ландтаг (по заявлению фракции или двадцати депутатов) может объявить, что считает условия, описанные в статье 44 конституции, фактически наступившими. Немецкие юристы Й.Ф. Линднер, М. Мёстл и Х.А. Вольф [4] отмечают, что, если же Министр-президент не исполняет свою обязанность подать в отставку в указанном выше случае, возможно обращение депутатов в конституционный суд Баварии на основании статей 59 и 64 конституции Баварии.

Кроме того, в 8 из 16 земель предусматривается возможность подачи запроса Министра-президента о выражении ему доверия. Если такой запрос не получает поддержки абсолютного большинства депутатов ландтага, у ландтага появляется право выбора нового Министра-президента. Однако в Бранденбурге (ст. 83 конституции земли) и Шлезвиг-Гольштейне (ст. 43 конституции земли) Министр-президент одновременно с этим получает право роспуска парламента. Аналогичное право роспуска парламента предусмотрено в ст. 36 Конституции Бремена, однако принадлежит данное право не Бургомистру (Министрупрезиденту), а всему сенату (Правительству).

Таким образом, Министр-президент в Германии интегрирован в систему органов публичной власти федеральной земли, формирование, наделение его соответствующими полномочиями и отстранение от занимаемой должности полная прерогатива законодательного усмотрения соответствующей земли как субъекта Федерации. Единственное, что связывает его с федеральным уровнем - возможное членство в верхней палате парламента - Бундесрате.

В свою очередь, согласно пункту «н» ч.1 ст. 72 Конституции Российской Федерации 1993 года установление общих принципов организации системы органов государственной власти относится к предметам совместного ведения Федерации и ее субъектов. Основы статуса высшего должностного лица субъекта Российской Федерации регламентируются нормами Федерального закона от 6 октября 1999 года № 184-Ф3 «Об общих принципах организации законодательных (представительных) и исполнительных органов государственной власти субъектов Российской Федерации» [37] (далее Федеральный закон №184-Ф3).

В субъектах Российской Федерации наблюдается разнообразие в наименовании высшего должностного лица. Так, в областях, краях и автономных округах это, как правило, губернатор, в республиках - президент или глава правительства республики, в Москве установлено наименование «мэр Москвы». Данное многообразие имеет формальное закрепление в п. 6 ст. 18 Федерального закона №184-Ф3.

По сравнению с германским законодательством, высшему должностному лицу субъекта Российской Федерации запрещается заниматься иной оплачиваемой деятельностью, кроме научной, творческой или преподавательской (пункт 4 ст. 18 Федерального закона №184-Ф3).

В соответствии с п. 3 ст. 18 Федерального закона №184-Ф3 высшее должностное лицо субъекта Российской Федерации (руководитель высшего исполнительного органа государственной власти субъекта Российской Федерации) избирается гражданами Российской Федерации, проживающими на территории данного субъекта Российской Федерации и обладающими в соответствии с федеральным законом активным избирательным правом, либо депутатами законодательного (представительного) органа государственной власти субъекта Федерации. 
Кандидаты на должность высшего должностного лица выдвигаются политическими партиями, однако, субъект Федерации может предусмотреть возможность и самовыдвижения кандидатов. Федеральный закон №184-Ф3 предусматривает право Президента Российской Федерации проводить по своей инициативе консультации с политическими партиями, выдвигающими кандидатов на должность высшего должностного лица субъекта Российской Федерации, а также с кандидатами, выдвинутыми на указанную должность в порядке самовыдвижения. Как нам кажется, такое право главы государства можно рассматривать как вмешательство со стороны федерального центра в лице Президента в прерогативу субъекта Федерации образовывать собственные органы государственной власти самостоятельно.

По нашему мнению, существующий ранее порядок наделения гражданина Российской Федерации полномочиями высшего должностного лица субъекта Федерации законодательным (представительным) органом государственной власти субъекта Федерации по представлению главы государства, был явным примером ограничения государственной самостоятельности субъекта образовывать собственные органы власти.

Более того, такой порядок вполне удачно вписался в атмосферу отечественного избирательного законодательства. Однако не вызывает никаких сомнений, что круг лиц, которые могут попасть в число потенциальных кандидатов на данную должность, существенно ограничивается, при этом нормы Конституции Российской Федерации о возможности каждого гражданина участвовать в управлении делами государства не нарушаются. В то же время, замена прямых выборов глав субъектов Федерации на процедуру наделения их полномочиями законодательным (представительным) органом субъекта Федерации по предложению Президента не соотносится с положением ч. 2 ст. 55 Конституции, в соответствии с которым не должны издаваться законы, отменяющие или умаляющие права и свободы человека и гражданина[31].

Отметим также, что гражданин, замещавший должность высшего должностного лица и отрешенный от этой должности Президентом Российской Федерации, в течение двух лет не может быть выдвинут кандидатом на указанную должность ни в одном субъекте Российской Федерации. В случае отставки высшего должностного лица по собственному желанию или в связи с недоверием законодательного органа, гражданин, замещавший эту должность, не может быть выдвинут кандидатом на выборах, назначенных в связи с указанными обстоятельствами.
Таким образом, процедура формирования главы субъекта Федерации претерпела изменения - пройдя путь от прямых выборов, через наделения гражданина полномочиями высшего должностного лица, возвращаясь к выборам с некоторыми коррективами. В настоящее время порядок избрания главы субъекта Федерации продолжает оставаться под, правда косвенным, контролем со стороны Президента. В данном случае речь идет о способах выдвижения кандидатов, инициативе Президента о проведении консультации с политическими партиями, выдвигающими кандидатов на должность высшего должного лица субъекта Федерации, равно как и с кандидатами-самовыдвиженцами[32]. Требование о поддержке кандидата со стороны 5-10\% депутатов представительных органов муниципальных образований и (или) избранных на муниципальных выборах глав муниципальных образований предопределяет определенного связь высшего должностного лица субъекта Федерации с органами местного самоуправления соответствующего субъекта Федерации, что, как правило, сказывается на эффективности их взаимодействия друг с другом.

В соответствии с пунктом 3.2 ст.18 Федерального закона №184-Ф3 предусматривается избрание высшего должностного лица законодательным (представительным) органом, если такая возможность предусматривается Конституцией (Уставом) субъекта Федерации. В то же время законом устанавливается так называемый «президентский фильтр»: политические партии, имеющие мандаты в региональном парламенте, вправе предложить Президенту Российской Федерации не более трех кандидатур на должность высшего должностного лица; по результатам рассмотрения всех предложения Президент представляет кандидатов парламенту субъекта Федерации. При этом перед представлением кандидатур Президенту «парламентские» партии обязаны провести консультации с партиями, не имеющими представительства в парламенте.

Согласно п. 5.2 ст. 18 Федерального закона №184-Ф3 в случае признания выборов высшего должностного лица субъекта Российской Федерации несостоявшимися или недействительными проводятся повторные выборы, а до вступления в должность избранного высшего должностного лица исполнение его обязанностей осуществляется лицом, назначенным Президентом Российской Федерации.

Сравнительный анализ объема компетенционных полномочий высшего должностного лица субъекта Российской Федерации и Министра-президента в Германии демонстрирует значительный перевес в пользу российского главы субъекта федерации. 
Также, как и Министр-президент, высшее должностное лицо субъекта Российской Федерации согласно п. 7 ст. 18 Федерального закона №184-Ф3 представляет свой субъект Федерации во внешних сношениях, формирует правительство, и обеспечивает его деятельность, а также осуществляет промульгацию законов субъекта Федерации. Кроме того, он вправе участвовать в работе законодательного (представительного) органа государственной власти субъекта Федерации с правом совещательного голоса и требовать его внеочередного созыва, что подтверждает его приоритетную роль в системе органов публичной власти регионального уровня.

Отметим также, что согласно ст. 7 Положения о Государственном совете Российской Федерации [38] высшие должностные лица (руководители высших исполнительных органов государственной власти) субъектов Российской Федерации являются членами Государственного совета РФ, что, как справедливо отмечает В.Г. Казаков, позволяет высшему должностному лицу региона влиять на выработку государственной политики и принятие важнейших политических решений [35].

Министры-президенты германских федеральных земель также участвуют в деятельности государства на федеральном уровне. Так, п. 1 ст. 51 Основного закона ФРГ 1949 года устанавливает, что членами Бундесрата («верхней» палаты немецкого парламента), являются представители земель, ими же и назначаемые. Как правило, это министр-президент и министры (от двух до пяти в зависимости от числа жителей конкретной федеральной земли). Однако данная норма не содержит императивности в отношении членства именно министров-президентов.

Досрочное прекращение полномочий высшего должностного лица согласно ст. 19 Федерального закона №184-Ф3 возможно по общим основаниям (смерть, признание его судом недееспособным или ограниченно дееспособным, объявление умершим или безвестно отсутствующим, вступление в законную силу обвинительного приговора суда и выезд за пределы Российской Федерации на постоянное место жительства). Как и в Германии, высшее должностное лицо прекращает исполнение своих полномочий в связи с добровольной отставкой, отзывом, инициированным гражданами, и выражением недоверия законодательным органом.

Кроме того, согласно п.п. «г» п.1 ст. 19 Федерального закона № 184-ФЗ Президент Российской Федерации может отрешить высшее должностное лицо субъекта Российской Федерации от исполнения полномочий в связи с утратой доверия Президента
Российской Федерации, а также за ненадлежащее исполнение своих обязанностей. Отметим, что действующее законодательство не содержит определения понятий «утрата доверия Президента» и «ненадлежащее исполнение обязанностей высшего должностного лица субъекта Российской Федерации», что позволяет говорить об использовании главой государства данной прерогативы по собственному усмотрению.

Так, например, Президент Российской Федерации может отрешить высшее должностное лицо субъекта Федерации от исполнения полномочий, руководствуясь политическими мотивами. В свою очередь свобода регионального парламента в принятии решения о выражении недоверия ограничена п. 2 ст.19 Федерального закона №184-Ф3, который устанавливает исчерпывающий перечень оснований для выражения недоверия:

- $\quad$ издание актов, противоречащих действующему законодательству;

- $\quad$ иное грубое нарушение действующего законодательства;

- $\quad$ ненадлежащего исполнения высшим должностным лицом своих обязанностей.

Небезынтересно, что в Германии премьер-министр земли может быть отрешен от должности из-за несогласия парламента с его политическим курсом, т.е. по абсолютно политическим мотивам. Этот механизм обеспечивает реализацию концепции политического консенсуса между органами публичной власти, являющимися участниками политического процесса. В России же отрешение высшего должностного лица субъекта Федерации парламентом возможно только в случае несоблюдения им законодательства либо его неэффективной деятельности, право отрешения его на основании политических мотивов принадлежит исключительно Президенту РФ.

Примечательно, что и в случае выражения высшему должностному лицу недоверия парламентом субъекта Федерации, отрешает его от должности Президент Российской Федерации, что ставит под сомнение бесспорность данного положения. По справедливому замечанию с А.А. Докторовой [33], целесообразнее было бы закрепить одного и того же субъекта в качестве источника наделения высшего должностного лица полномочиями и лишения их.

Аналогично регламентирована процедура отзыва, основы которого устанавливаются в п. 7 ст. 19 Федерального закона № 184-ФЗ. Согласно п. 7.3 указанной статьи политические партии, общественные объединения и группа граждан, не менее 100 человек, вправе обратиться в суд субъекта Федерации с заявлением об установлении фактов, являющихся основаниями для отзыва: 
a) нарушение высшим должностным лицом субъекта Федерации законодательства Российской Федерации и (или) законодательства субъекта Российской Федерации;

б) неоднократное грубое без уважительных причин неисполнение высшим должностным лицом своих обязанностей, установленное соответствующим судом.

Право граждан и общественных объединений на отзыв высшего должностного лица субъекта Федерации в связи с несогласием с проводимой им политикой и избранным курсом в Российской Федерации не предусматривается, однако в Германии оно действует в некоторых федеральных землях.

Следует иметь в виду, что в подавляющем большинстве случаев, лицо, временно исполняющее обязанности высшего должностного лица, назначается Президентом Российской Федерации (п. 9 ст. 19 Федерального закона № 184-Ф3).

Проведённый сравнительно-правовой анализ института главы субъекта Российской Федерации и министра-президента федеральной земли в Германии позволяет говорить о схожести их конституционно-правового регулирования. В частности, и в Германии, и в Российской Федерации действуют аналогичные запреты для глав субъектов федерации занимать иные должности и заниматься иной оплачиваемой деятельностью, используется один из двух возможных механизмов наделения высшего должностного лица полномочиями - выборы его парламентом субъекта федерации.

Однако, безусловно, имеют место отличия, обусловленные спецификой национального законодательства рассматриваемых стран. Так, основы статуса министра-президента федеральной земли закрепляются в конституции соответствующей земли, тогда как в России основные принципы организации высшего должностного лица субъекта устанавливаются на федеральном уровне с достаточно детальным регулированием, оставляя субъектам Федерации незначительную свободу правотворчества. В то же время в Германии в отношении многих элементов правового статуса министра-президента отсутствуют нормативные предписания и требуется применение способов восполнения пробелов права путем аналогии закона (требования к кандидату на должность, срок избрания министра-президента, санкции за нарушение такого срока, последствия отклонения запроса о выражении парламентом доверия министру-президенту).

Министр-президент федеральной земли избирается исключительно парламентом земли и несет перед ним ответственность. Он полностью интегрирован в структуру органов публичной власти федеральной земли и взаимодействует с федеральным уровнем власти только в рамках представительских функций, в том числе, членства в Бундесрате - палате представительства земель. В свою очередь в России широкое влияние на высшее должностное лицо субъекта Федерации имеет глава государства.

Интересно отметить, что право помилования в Германии принадлежит министру-президенту, а не главе государства, как в России, что еще раз подчеркивает большую степень самостоятельности федеральных земель и министра-президента в сравнении с российскими субъектами федерации.

В случае необходимости переизбрания министра-президента он осуществляет свои полномочия до вступления в должность преемника, тогда как в России временно исполняющего обязанности высшего должностного лица назначает глава государства.

Кроме того, важным демократическим инструментом является право отзыва министра-президента депутатами регионального парламента и (в некоторых федеральных землях) гражданами в связи с несогласием с его политическим курсом. В России же только Президент может отозвать высшее должностное лицо по политическим мотивам, все остальные субъекты, правомочные инициировать лишение высшего должностного лица полномочий, могут использовать свое право лишь в случае неоднократного грубого без уважительных причин неисполнения высшим должностным лицом своих обязанностей, установленное соответствующим судом, либо нарушение им федерального законодательства или законодательства субъекта Федерации.

Подводя итог, отметим, что высшее должностное лицо субъекта Российской Федерации и министрпрезидент федеральной земли в Германии являются главами субъектов федерации и возглавляют региональные правительства, имеют схожую компетенцию, порядок формирования и лишения полномочий, а также являются опосредованными субъектами федеральной политики. Однако национальные особенности каждого из этих институтов предопределяют место главы региона в системе органов публичной власти.

Если же министр-президент интегрирован в систему органов власти федеральной земли и является независимым, в известном смысле, органом государственной власти субъекта Федерации по сравнению с федеральными органами, то высшее должностное лицо субъекта Российской Федерации имеет опосредованное (косвенное) зависимость от федерального уровня государственной власти, а именно от Президента Российской Федерации. Вместе с тем, в 
законодательстве Российской Федерации содержатся нормы, закрепляющие отдельны элементы правового статуса «независимого» высшего должностного лица, избираемого или непосредственно гражданами или законодательным (представительным) органом соответствующего субъекта Федерации.

На основании вышеизложенного, полагаем, что Федеральный закон №184-Ф3 предусматривает возможность использования двух моделей организационно-правовой деятельности главы субъекта Российской Федерации. Первая модель («децентрализованная») предполагает значительную степень самостоятельности субъекта Федерации и его обособленности от федерального уровня. К числу характеризующих ее особенностей, можно отнести следующие:

- избрание высшего должностного лица гражданами субъекта Федерации или избирания его законодательным (представительным) органом субъекта Федерации;

- $\quad$ требование о поддержке кандидата со стороны 5-10\% депутатов представительных органов муниципальных образований и (или) избранных на муниципальных выборах глав муниципальных образований;

- $\quad$ отзыв высшего должностного лица гражданами или общественными объединениями и формальная возможность выражения ему недоверия законодательным (представительным) органом субъекта Федерации.

Вторая модель («цеентрализованная») предусматривает участие Президента Российской Федерации в процессе избрания высшего должностного лица субъекта Федерации, что находит свое выражение в таких признаках как:

- $\quad$ консультации Президента с кандидатами на должность высшего должностного лица;

- $\quad$ отбор Президентом кандидатур для представления в законодательный (представительный) орган субъекта трех кандидатур;

- отрешение высшего должностного лица Президентом фактически на основании политических мотивов;

- $\quad$ определяющее решение Президента при выражении парламентом недоверия высшему должностному лицу;

- $\quad$ право Президента назначать временно исполняющего обязанности высшего должностного лица субъекта Федерации;

- членство высших должностных лиц субъектов Федерации в Государственном совете.

Каждая из этих моделей может быть использована в организационно-правовой деятельности главы субъекта Российской Федерации. Однако , как видно, они содержат в себе различные подходы к организации института высшего должностного лица. По нашему мнению, при выборе модели организационно-правовой деятельности главы субъекта Российской Федерации стоит руководствоваться не только приоритетами государственного и общественного развития, конституционными принципами функционирования государства, но и оптимальностью ее (модели) применения.

Вместе с тем, целесообразным представляется заимствование германского опыта, использование которого позволило бы органически дополнить и закрепить в России «децентрализованную» модель, соответствующую провозглашаемым принципам федерализма. В этом смысле, предлагается, вопервых, закрепить единый способ наделения высшего должностного лица полномочиями (например, самостоятельное избрание высшего должностного лица субъекта Федерации депутатами регионального парламента без участия Президента Российской Федерации). Это позволит говорить о самостоятельности и политической самодостаточности парламента субъекта Федерации, что может повысить роль и значение законодательного (представительного) органа власти субъекта Федерации в публичном управлении соответствующим регионом.

Кроме того, деятельность высшего должностного лица субъекта Федерации требует не только взаимодействия, но и возможности достижения политического консенсуса с иными органами государственной власти субъекта Федерации, соответственно избрание главы субъекта депутатами регионального парламента будет предполагать наличие такого консенсуса (той же цели служит и так называемый «муниципальный фильтр»). Также стоит отметить, что этот способ формирования высшего должностного лица представляется более «экономичным» по сравнению с материально-финансовыми затратами, связанные с процедурой проведения выборов непосредственно гражданами.

Во-вторых, срок полномочий высшего должностного лица должен быть поставлен в зависимость от срока полномочий регионального парламента. Предполагается, что вновь избранный законодательный (представительный) орган субъекта Федерации в течение установленного срока избирает высшее должностное лицо субъекта Федерации, осуществляющее свои полномочия до избрания парламентом следующего созыва нового высшего должностного лица субъекта Федерации. Также стоит закрепить ответственность парламен- 
та за неизбрание высшего должностного лица в течение установленного законом срока. Поскольку невозможность договориться о кандидатуре главы субъекта Федерации является следствием неспособности депутатов к выработке консенсуального решения, объективной мерой ответственности представляется роспуск парламента.

В-третьих, высшее должностное лицо субъекта Федерации должно нести ответственность перед парламентом, его избравшим, и перед гражданами соответствующего субъекта Федерации, соответственно - и депутаты регионально парламента, и граждане должны иметь право отзыва главы субъекта Федерации. При этом, полагаем, что целесообразно сохранить за Президентом Российской Федерации право лишения полномочий только на основании объективных критериев (например, вследствие неоднократного грубого без уважительных причин неисполнения высшим должностным лицом своих обязанностей, нарушения как федерального, так и регионального и принятие нормативно-правовых актов, противоречащих законодательству). В связи с этим во избежание злоупотребления, подлежит исключению не совсем ясное с юридической точки зрения и, носящие субъективный характер, такое основание прекращения полномочий главы субъекта Федерации как «утрата доверия». Видится нецелесообразным лишение полномочий главы региона из-за утраты доверия Президента Российской Федерации, если при этом глава региона продолжает пользоваться поддержкой в соответствующем субъекте Федерации, то есть Президент может отстранить его от должности только при наличии объективных оснований.

Таким образом, целесообразно заимствовать нормы, обеспечивающие большую независимость высшего должностного лица субъекта Федерации от федеральной власти и более тесную его связь с регионом, главой которого он является. Использование позитивного германского опыта организации института министра-президента представляется полезным для укрепления федеративных основ осуществления государственного управления в Российской Федерации и совершенствования отечественного законодательства.

\section{Библиография:}

1. Bundeswahlgesetz// Интернет-портал издательства Beck „Beckonline. Die Databank“ https://beck-online.beck. $\mathrm{de} /$ ?typ $=$ reference $\& \mathrm{Y}=100 \& \mathrm{G}=\mathrm{BWG}$.

2. $\quad$ BVerfGE $62,1=$ NJW 1983, 735//http://verfassungsrecht.ch.

3. BVerfGE $62,38 / / \mathrm{http}: / /$ verfassungsrecht.ch.

4. Dr. Josef Franz Lindner Verfassung des Freistaates Bayern. Kommentar/ Dr. Josef Franz Lindner, Dr. Markus Möstl, Dr. Heinrich Amadeus Wollf München: Verlag C.H.Beck. 2009. wieviel Seiten. S. 278.

5. Geschäftsordnung für den Bayerischen Landtag (BayLTGeschO) // Интернет-портал издательства Beck „Beck online. Die Databank" https://beck-online.beck.de/?bcid=Y-100-G-BayLTGO.

6. Grundgesetz für die Bundesrepublik Deutschland Kommentar von Prof. Dr. Hans D. Jarass, LL.M., Prof. Dr. Bodo Pieroth München, Verlag C.H. Beck oHG. 2014. 1329 s.

7. Grundgesetz für die Bundesrepublik Deutschland // Интернет-портал Издательства Beck „Beck online. Die Databank“ https://beck-online.beck.de/?vpath=bibdata\%2Fges\%2FGG\%2Fcont\%2FGG.htm.

8. Klaus David Verfassung der Freien und Hansestadt Hamburg: Kommentar Stuttgart. 2004. 1209 S. S. 691.

9. Niedersächsische Verfassung // Интернет-портал издательства Beck „Beck online. Die Databank“ https://beck-online.beck. de/?bcid=Y-100-G-NdsVerf.

10. Verfassung der Freien und Hansestadt Hamburg//// Интернет-портал издательства Beck „Beck online. Die Databank“ https://beck-online.beck.de/?bcid=Y-100-G-HbgVerf.

11. Verfassung des Freistaates Bayern // Интернет-портал издательства Beck „Beck online. Die Databank“ https://beck-online. beck.de/?bcid=Y-100-G-BayVerf.

12. Verfassung des Freistaates Bremen // Интернет-портал издательства Beck „Beck online. Die Databank“ https://beck-online. beck.de/?bcid=Y-100-G-BayVerf.

13. Verfassung des Freistaates Sachsen // Интернет-портал издательства Beck „Beck online. Die Databank“https://beck-online. beck.de/?bcid=Y-100-G-SaVerf.

14. Verfassung des Freistaats Thüringen // Интернет-портал издательства Beck „Beck online. Die Databank“ https://beckonline.beck.de/?bcid=Y-100-G-ThVerf.

15. Verfassung des Landes Baden-Württemberg// Интернет-портал издательства Beck „Beck online. Die Databank“ https:// beck-online.beck.de/?bcid=Y-100-G-BWLV.

16. Verfassung des Landes Brandenburg// Интернет-портал издательства Beck „Beck online. Die Databank“ https://beckonline.beck.de/?bcid=Y-100-G-BbgVerf.

17. Verfassung des Landes Hessen // Интернет-портал издательства Beck „Beck online. Die Databank“ https://beck-online. beck.de/?bcid=Y-100-G-HEV.

18. Verfassung des Landes Mecklenburg-Vorpommern // Интернет-портал издательства Beck „Beck online. Die Databank“ https://beck-online.beck.de/?bcid=Y-100-G-MVVerf. 
19. Verfassung des Landes Sachsen-Anhalt // Интернет-портал издательства Beck „Beck online. Die Databank“ https://beckonline.beck.de/?bcid=Y-100-G-LsaVerf.

20. Verfassung des Landes Schleswig-Holstein// Интернет-портал издательства Beck „Beck online. Die Databank“ https:// beck-online.beck.de/?bcid=Y-100-G-ShVerf.

21. Verfassung des Saarlandes // Интернет-портал издательства Beck „Beck online. Die Databank“ https://beck-online.beck. $\mathrm{de} /$ ?bcid=Y-100-G-SaarVerf.

22. Verfassung für das Land Nordrhein-Westfalen// Интернет-портал издательства Beck „Beck online. Die Databank“ https:// beck-online.beck.de/?vpath=bibdata/ges/nwverf/cont/nwverf.htm\&mode=gesamt\&page=1.

23. Verfassung für Rheinland-Pfalz// Интернет-портал издательства Beck „Beck online. Die Databank“ https://beck-online. beck.de/?bcid=Y-100-G-RpfVerf.

24. Verfassung von Berlin// Интернет-портал издательства Beck „Beck online. Die Databank“ https://beck-online.beck. $\mathrm{de} /$ ?bcid $=$ Y-100-G-BlnVerf.

25. Geschäftsordnung des Abgeordnetenhauses von Berlin// Интернет-портал издательства Beck, Beck online. Die Databank“ https://beck-online.beck.de/?bcid=Y-100-G-BlnAbghGO.

26. Geschäftsordnung für den Bayerischen Landtag// Интернет-портал издательства Beck „Beck online. Die Databank“ https:// beck-online.beck.de/?bcid=Y-100-G-BayLTGO.

27. Geschäftsordnung des Landtags von Baden-Württemberg// Интернет-портал издательства Beck „Beck online. Die Databank“ https://beck-online.beck.de/?bcid=Y-100-G-BWLTGO.

28. Geschäftsordnung des Landtags Rheinland-Pfalz// Интернет-портал издательства Beck „Beck online. Die Databank“ https://beck-online.beck.de/?bcid=Y-100-G-RPGOLTag.

29. Geschäftsordnung des Schleswig-Holsteinischen Landtages// Интернет-портал издательства Beck „Beck online. Die Databank" https://beck-online.beck.de/?bcid=Y-100-G-SHLTGeschO.

30. Wilhelm Drexelius, Renatus Weber Die Verfassung der Freien und Hansestadt Hamburg. Kommentar. Berlin: Walter de Gruyeter. 1972. 293 S. S. 89-90.

31. Авдеев Д.А. Избиратели как источник власти, или юридическое измерение категории «народ» // Современное право. 2015. № 11. С. 28.

32. Авдеев Д.А. Опыт первого двадцатилетия пятой российской Конституции // Конституционное и муниципальное право. 2014. № 1. С. 19.

33. Докторова А.Т. К вопросу о конституционно-правовой ответственности высшего должностного лица субъекта Российской Федерации // Журнал «Бизнес, менеджмент и право». 2011. № 2. http://www.bmpravo.ru/show_stat.php?stat=828.

34. Гессен В.М. О правовом государстве СПб., 1906. 56 с.

35. Казаков В.Г. Институт высшего должностного лица субъекта Российской Федерации в условиях реформирования политико-административных отношений: Дис. канд. полит. наук. М., 2004. 171 с.

36. Романович-Словатинский А.В. Исторический очерк губернского учреждения от первых преобразований Петра Великого до учреждения губерний в 1775 году. г. Казань, 1859. 124 с.

37. Федеральный закон от 6 октября 1999 года № 184-Ф3 «Об общих принципах организации законодательных (представительных) и исполнительных органов государственной власти субъектов Российской Федерации» // Собрание законодательства Российской Федерации. 1999. № 42. Ст. 5005.

38. Указ Президента РФ от 1 сентября 2000 года № 1602 «О Государственном совете Российской Федерации» // Собрании законодательства Российской Федерации. 2000. № 36. Ст. 3633.

\section{References (transliterated):}

1. Dr. Josef Franz Lindner Verfassung des Freistaates Bayern. Kommentar/ Dr. Josef Franz Lindner, Dr. Markus Möstl, Dr. Heinrich Amadeus Wollf München: Verlag C.H.Beck. 2009. wieviel Seiten. S. 278.

2. Geschäftsordnung für den Bayerischen Landtag (BayLTGeschO) // Internet-portal izdatel'stva Beck „Beck online. Die Databank" https://beck-online.beck.de/?bcid=Y-100-G-BayLTGO.

3. Grundgesetz für die Bundesrepublik Deutschland Kommentar von Prof. Dr. Hans D. Jarass, LL.M., Prof. Dr. Bodo Pieroth München, Verlag C.H. Beck oHG. 2014. 1329 s.

4. Grundgesetz für die Bundesrepublik Deutschland // Internet-portal Izdatel'stva Beck „Beck online. Die Databank“ https:// beck-online.beck.de/?vpath=bibdata $\% 2$ Fges $\% 2$ FGG $\% 2$ Fcont $\% 2$ FGG.htm.

5. Klaus David Verfassung der Freien und Hansestadt Hamburg: Kommentar Stuttgart. 2004. 1209 S. S. 691.

6. Niedersächsische Verfassung // Internet-portal izdatel'stva Beck „Beck online. Die Databank“ https://beck-online.beck. de/?bcid=Y-100-G-NdsVerf.

7. Verfassung der Freien und Hansestadt Hamburg//// Internet-portal izdatel'stva Beck „Beck online. Die Databank“ https:// beck-online.beck.de/?bcid=Y-100-G-HbgVerf.

8. Verfassung des Freistaates Bayern // Internet-portal izdatel'stva Beck „Beck online. Die Databank“ https://beck-online.beck. de/?bcid=Y-100-G-BayVerf.

9. Verfassung des Freistaates Bremen // Internet-portal izdatel'stva Beck „Beck online. Die Databank“ https://beck-online.beck. de/?bcid=Y-100-G-BayVerf.

10. Verfassung des Freistaates Sachsen // Internet-portal izdatel'stva Beck „Beck online. Die Databank“ https://beck-online.beck. de/?bcid=Y-100-G-SaVerf. 
DOI: $10.7256 / 1811-9018.2016 .3 .18315$

При цитировании этой статьи сноска на dоі обязательна

Право и политика $3(195) \cdot 2016$

11. Verfassung des Freistaats Thüringen // Internet-portal izdatel'stva Beck „Beck online. Die Databank“ https://beck-online. beck.de/?bcid=Y-100-G-ThVerf.

12. Verfassung des Landes Baden-Württemberg// Internet-portal izdatel'stva Beck „Beck online. Die Databank“ https://beckonline.beck.de/?bcid=Y-100-G-BWLV.

13. Verfassung des Landes Brandenburg// Internet-portal izdatel'stva Beck „Beck online. Die Databank“ https://beck-online. beck.de/?bcid=Y-100-G-BbgVerf.

14. Verfassung des Landes Hessen // Internet-portal izdatel'stva Beck „Beck online. Die Databank“ https://beck-online.beck. de/?bcid=Y-100-G-HEV.

15. Verfassung des Landes Mecklenburg-Vorpommern // Internet-portal izdatel'stva Beck „Beck online. Die Databank“ https:// beck-online.beck.de/?bcid=Y-100-G-MVVerf.

16. Verfassung des Landes Sachsen-Anhalt// Internet-portal izdatel'stva Beck „Beck online. Die Databank“ https://beck-online. beck.de/?bcid=Y-100-G-LsaVerf.

17. Verfassung des Landes Schleswig-Holstein// Internet-portal izdatel'stva Beck „Beck online. Die Databank“ https://beckonline.beck.de/?bcid=Y-100-G-ShVerf.

18. Verfassung des Saarlandes // Internet-portal izdatel'stva Beck „Beck online. Die Databank“ https://beck-online.beck. de/?bcid=Y-100-G-SaarVerf.

19. Verfassung für das Land Nordrhein-Westfalen// Internet-portal izdatel'stva Beck „Beck online. Die Databank“ https://beckonline.beck.de/?vpath=bibdata/ges/nwverf/cont/nwverf.htm\&mode=gesamt\&page=1

20. Verfassung für Rheinland-Pfalz// Internet-portal izdatel'stva Beck „Beck online. Die Databank“ https://beck-online.beck. de/?bcid=Y-100-G-RpfVerf.

21. Verfassung von Berlin// Internet-portal izdatel'stva Beck „Beck online. Die Databank“ https://beck-online.beck.de/?bcid=Y$100-\mathrm{G}-\mathrm{B} \ln V e r f$.

22. Geschäftsordnung des Abgeordnetenhauses von Berlin// Internet-portal izdatel'stva Beck „Beck online. Die Databank“ https:// beck-online.beck.de/?bcid=Y-100-G-BlnAbghGO.

23. Geschäftsordnung für den Bayerischen Landtag// Internet-portal izdatel'stva Beck „Beck online. Die Databank“ https://beckonline.beck.de/?bcid=Y-100-G-BayLTGO.

24. Geschäftsordnung des Landtags von Baden-Württemberg// Internet-portal izdatel'stva Beck „Beck online. Die Databank“ https://beck-online.beck.de/?bcid=Y-100-G-BWLTGO.

25. Geschäftsordnung des Landtags Rheinland-Pfalz// Internet-portal izdatel'stva Beck „Beck online. Die Databank“ https:// beck-online.beck.de/?bcid=Y-100-G-RPGOLTag.

26. Geschäftsordnung des Schleswig-Holsteinischen Landtages// Internet-portal izdatel'stva Beck „Beck online. Die Databank“ https://beck-online.beck.de/?bcid=Y-100-G-SHLTGeschO.

27. Wilhelm Drexelius, Renatus Weber Die Verfassung der Freien und Hansestadt Hamburg. Kommentar. Berlin: Walter de Gruyeter. 1972. 293 S. S. 89-90.

28. Avdeev D.A. Izbirateli kak istochnik vlasti, ili yuridicheskoe izmerenie kategorii «narod» // Sovremennoe pravo. 2015. № 11. S. 28.

29. Avdeev D.A. Opyt pervogo dvadtsatiletiya pyatoi rossiiskoi Konstitutsii // Konstitutsionnoe i munitsipal'noe pravo. 2014. № 1. S. 19 .

30. Doktorova A.T. K voprosu o konstitutsionno-pravovoi otvetstvennosti vysshego dolzhnostnogo litsa sub"ekta Rossiiskoi Federatsii // Zhurnal «Biznes, menedzhment i pravo». 2011. № 2. http://www.bmpravo.ru/show_stat.php?stat=828.

31. Gessen V.M. O pravovom gosudarstve SPb., 1906. 56 s.

32. Kazakov V.G. Institut vysshego dolzhnostnogo litsa sub"ekta Rossiiskoi Federatsii v usloviyakh reformirovaniya politikoadministrativnykh otnoshenii: Dis. kand. polit. nauk. M., 2004. $171 \mathrm{c}$.

33. Romanovich-Slovatinskii A.V. Istoricheskii ocherk gubernskogo uchrezhdeniya ot pervykh preobrazovanii Petra Velikogo do uchrezhdeniya gubernii v 1775 godu. g. Kazan', 1859. 124 s. 